\title{
Reproductive toxicity of heavy metals in fallow deer in vitro
}

\author{
Ehdaa Eltayeb Eltigani Abdelsalam, Hana Band'ouchová, Tomáš Heger, \\ Miroslava Kaňová, Kateřina Kobelková, Monika Němcová, Vladimír Piaček, \\ Jana Sedláčková, Veronika Seidlová, František Vitula, Jiř́i Pikula \\ University of Veterinary Sciences Brno, Faculty of Veterinary Hygiene and Ecology, \\ Department of Ecology and Diseases of Zoo Animals, Game, Fish, and Bees, Brno, Czech Republic
}

Received October 21, 2020

Accepted August 31, 2021

\begin{abstract}
Sertoli cells play a crucial role in male fertility through boosting and regulating the differentiation of spermatogonial stem cells into mature sperm during spermatogenesis. Female ovarian follicles are responsible for the production of mature ova and control of ovarian steroidogenesis. Disruption of these structures through exposure to environmental pollutants is critical for reproductive health. Here, we derived primary cell cultures of Sertoli cells and ovarian follicles from fallow deer (Dama dama). Cells were used as in vitro models to explore reproductive toxicity of heavy metals in wild species. Adverse effects of cadmium $\left(\mathrm{CdCl}_{2}\right)$, methylmercury $\left(\mathrm{MeHgCl}_{2}\right)$, and lead $\left(\mathrm{PbCl}_{2}\right)$ were investigated through a range of equal molar concentrations $(0,15,30,60,125,250 \mu \mathrm{M})$. We found both concentration-dependent and independent cytotoxic patterns $(P<0.01, P<0.05)$ in cells exposed to $\mathrm{CdCl}_{2}, \mathrm{MeHgCl}_{2}$, and $\mathrm{PbCl}_{2}$. Based on generation of lipid hydroperoxides, significant levels of cell oxidative perturbation were detected in the $\mathrm{CdCl}_{2}(P=0.0001), \mathrm{PbCl}_{2}$ $(P=0.001)$, and $\mathrm{MeHgCl}_{2}(P=0.003)$ groups. Likewise, the antioxidant enzymes catalase and glutathione peroxidase were inhibited in all metal-treated groups $(P<0.01)$. Genotoxic DNA damage (single-strand break) was also observed ( $\mathrm{MeHgCl}_{2}$ group, $P=0.002 ; \mathrm{CdCl}_{2}$ and $\mathrm{PbCl}_{2}$ groups, $P=0.004)$. Increased activity of superoxide dismutase $(P=0.0002$ and $P=0.01)$ was observed in $\mathrm{MeHgCl}_{2}$ and $\mathrm{CdCl}_{2}$, respectively. Cell apoptosis was detected in all the $\mathrm{PbCl}_{2}$ and $\mathrm{CdCl}_{2}(P=0.00007)$ and $\mathrm{MeHgCl}_{2}(P=0.001)$ groups. The results of this study can be used to characterize the responsiveness of fallow deer gonadal cells to the stress of toxic metal exposure.
\end{abstract}

Wildlife, reproductive organ-derived cells, cadmium, lead, methylmercury, adverse effects

Herbivorous game mammals have been frequently used as bioindicators for environmental contamination. Studies on cervid species from different habitats have reported bioaccumulation of toxic metals such as cadmium $(\mathrm{Cd})$, lead $(\mathrm{Pb})$, and mercury $(\mathrm{Hg})$ in their tissues (Čelechovská et al. 2008; Garcia et al. 2011; Kuiters 1996; Lazarus et al. 2008; Pokorny 2000).

Risks from heavy metal pollution are primarily attributed to their ability to persist in the environment. Continuous exposure to these contaminants may result in bioaccumulation in the biota, causing them to move up the food chain. After intake by an organism, heavy metals are distributed through body systems via molecule-binding and deposit in different tissues and organs. While excretion of heavy metals can extend over months, metal residues may remain within tissues throughout the animal's life (Pokorny 2000; Garcia et al. 2011). These residues may cause distinct physiological disruptions and adverse health effects.

Following absorption of heavy metals, mammalian cells phagocytose, partition and metabolize the heavy metal particles. This allows metal ions to form complexes with specific biological molecules intracellularly (Ariza et al. 1999; Singerman 2000). Cadmium and mercury, for example, are distributed in tissues by binding to the sulphhydryl

Address for correspondence:

E.E.E. Abdelsalam, J. Pikula

Department of Ecology and Diseases of Zoo Animals, Game, Fish, and Bees

Faculty of Veterinary Hygiene and Ecology

University of Veterinary Sciences Brno

Palackého tř. 1946/1

61242 Brno, Czech Republic 
group, containing molecules such as metallothionein, glutathione, and cysteine. On the other hand, $\mathrm{Pb}$ shows no affinity for binding to low molecular weight proteins, including groups of dicarboxylic amino acids (Fowler 1998). In both cases, however, organ-specific distribution and abundance occurs in particular structures. The accumulation of heavy metals in some tissues can also provide a persistent source of low dose toxicity through constant intracellular bioavailability of the toxic metal (Ariza et al. 1999; Fowler 1998; Svoboda et al. 2020).

In the present study, we explore the reproductive toxicity of $\mathrm{Cd}$, methylmercury $(\mathrm{MeHg})$, and $\mathrm{Pb}$ to fallow deer (Dama dama) using primary cell culture models. The animals employed in the study were obtained from an area previously investigated for heavy metal accumulation in the food chain, whereby specimens of soil, vegetation and animal tissue were examined for contamination with $\mathrm{Cd}, \mathrm{Hg}$, and $\mathrm{Pb}$ (Čelechovská et al. 2008). Accordingly, we assumed that there could be potential reproductive toxicity associated with these toxicants, based on an anticipated bioaccumulation of $\mathrm{Cd}, \mathrm{Hg}$, and $\mathrm{Pb}$ in the gonadal tissues of exposed game animal species. According to previous laboratory investigations, these substances are deposited in the gonads of exposed animals, with bioaccumulation being connected to physiological, biochemical, and morphological alterations (Stadnicka 1980; Wadi and Ahmad 1999; Taupeau et al. 2001; Penna et al. 2009; Wang et al. 2015; Cupertino et al. 2017). To confirm this, we obtained primary cultures of Sertoli cells and ovarian follicles derived from the gonadal tissue of fallow deer. Cell culturing models then allowed us to assess the toxicity of heavy metals on gonadal structures fundamental for fertility in this important game animal species.

\section{Materials and Methods}

Sertoli cells isolation and culture

Testicles were aseptically removed from a fresh, ca. 8-month-old, rifle gun-killed male fallow deer (Morris 1972). The testicle tissue was immediately placed into sterile cold $\left(4^{\circ} \mathrm{C}\right)$ physiological buffer saline (PBS) supplemented with penicillin-streptomycin for transfer to the laboratory within $2 \mathrm{~h}$, where the tunica albuginea was carefully removed to expose the testicular tissue. The seminiferous tubules were minced into small pieces (3-4 mm) in a culture medium consisting of Dulbecco's Modified Eagle Medium with $4.5 \mathrm{~g} / 1$ glucose and L-glutamine: BioWhittaker ${ }^{\circledR}$ DMEM:F12 (Bioscience Lonza, Verviers, Belgium) containing $1 \mathrm{mg} / \mathrm{ml}$ collagenase II (Life Technologies Corporation, Grand Island, NY, USA) and $1 \mathrm{mg} / \mathrm{ml}$ trypsin 1:25 (Sigma-Aldrich Co., Saint Louis, MO, USA). The cells were then incubated at $37^{\circ} \mathrm{C}$ on a shaker $(400 \mathrm{cycle} / \mathrm{min})$ for $40 \mathrm{~min}$. The cells were then submitted to secondary enzymatic digestion in DMEM:F12 containing $5 \mu \mathrm{g} / \mathrm{ml}$ DNase I (STEMCELL ${ }^{\text {TM }}$ Technologies Canada Inc. Vancouver, British Columbia, Canada) and incubated on a shaker for $15 \mathrm{~min}\left(37^{\circ} \mathrm{C}\right)$, following which they were passed through a $100 \mu \mathrm{m}$ Corning ${ }^{\mathbb{R}} 100 \mu \mathrm{m}$ Cell Strainer (Corning Incorporated. Corning, NY, USA). The resultant cell pellet was re-suspended in fresh complete medium consisting of DMEM:F12 with ML-glutamine and high glucose, 10\% foetal bovine serum (FBS) (Bioscience Lonza) and 1\% penicillin-streptomycin (Sigma-Aldrich Co.). The cells were then cultured in pre-prepared Datura stramoniumlectin (DSA-Lectin) coated flasks to separate the Sertoli cells from other germ cells. The flasks were also processed with bovine serum albumin (BSA) (Sigma-Aldrich Co.) prior to cell plating to reduce any unspecific binding of cells and to enable rapid growth of Sertoli cells (Kala et al. 2012). The cells were allowed to grow at $37{ }^{\circ} \mathrm{C}$ and $5 \% \mathrm{CO}_{2}$ overnight. Non-adherent cells were discharged and the medium was replaced after $18 \mathrm{~h}$.

Ovarian follicle cell isolation and culture

Ovaries were aseptically removed from a fresh, ca. 3-year-old, rifle gun-killed, female fallow deer. Ovarian tissue was obtained in a similar manner and under similar conditions as for testicular tissue (see above). All fat, ovarian surface epithelia and tunica albuginea were cut off to expose the ovarian cortex. The ovarian tissue was then fragmented into small pieces and grown in six-well culture plates containing DMEM:F12 supplemented with $10 \% \mathrm{FBS}$ and $1 \%$ penicillin-streptomycin in a controlled culture environment at $37{ }^{\circ} \mathrm{C}$ and $5 \% \mathrm{CO}_{2}$. The growing ovarian follicles surrounded by a stromal cell layer were then transferred into culture flasks kept under controlled optimal cell culturing conditions (Swim and Parker 1958) for further processing.

Preparation of heavy metals for testing

Cadmium chloride $\left(\mathrm{CdCl}_{2}\right)$, methyl mercuric chloride $\left(\mathrm{MeHgCl}_{2}\right)$, and lead chloride $\left(\mathrm{PbCl}_{2}\right)$ (Sigma-Aldrich Co.) were dissolved in suitable solvents $\left(\mathrm{dH}_{2} \mathrm{O}_{2}+\right.$ culture medium or PBS). The solutions were sterilized by filtration using a $0.22 \mu \mathrm{m}$ syringe filter. Equal molar solutions of each metal $(0,15,30,60,125$ and $250 \mu \mathrm{M})$ were then 
prepared by conducting serial dilutions in convenient culture or assay media without further additives. The metal solutions were either used immediately or stored at $4{ }^{\circ} \mathrm{C}$ for further use. The tested exposure ranges of reproductive cells to heavy metals under study were wider than the tissue concentrations reported for wild game ungulates from different habitats (Kuiters 1996; Čelechovská et al. 2008; Lazarus et al. 2008; Pokorny 2000; Garcia et al. 2011).

\section{Cytotoxicity assay}

Cytotoxicity, demonstrated by cell membrane damage, was determined via assessment of lactate dehydrogenase (LDH) leakage from metal-treated cells, using the Cytotoxicity Detection Kit ${ }^{\text {PLUS }}$ (LDH) (Roche Diagnostics $\mathrm{GmbH}$, Mannheim, Germany). Cells were cultured in 96-well plates at a density of $1 \times 10^{4}$ cells per well for $48 \mathrm{~h}$ before exposure to the metals. Culture media were then replaced by a previously prepared assay media consisting of DMEM w/o sodium pyruvate (Biosera, Nuaille, France) containing $0,15,30,60,125$ and $250 \mu \mathrm{M}$ of $\mathrm{CdCl}_{2}, \mathrm{MeHgCl}_{2}$, and $\mathrm{PbCl}_{2}$ for $24 \mathrm{~h}$. The assay was performed following the manufacturer's instructions. Activity of LDH was determined at $490 \mathrm{~nm}$ using an EL $\times 808$ multi-plate reader (BioTek ${ }^{\circledR}$ Instruments, Inc. Winooski, Vermont, USA).

\section{Assessment of lipid peroxidation}

Generation of lipid peroxidation (LPO) was assessed as a marker of oxidative cell membrane damage. Determination of LPO levels was conducted using the Lipid Hydroperoxide (LPO) Assay Kit (96 well) (Cayman Chemical, Ann Arbor, MI, USA), according to the manufacturer's instructions. Cells were grown in 12-well plates at a density of $1 \times 10^{4}$ cells per well for $48 \mathrm{~h}$, following which treatments were added for $24 \mathrm{~h}$. A lipid hydroperoxide extraction step was conducted prior to the assay using chloroform. Extracted samples were stored for a short period at $-80^{\circ} \mathrm{C}$ prior to assessment. Sample absorbance was measured at $500 \mathrm{~nm}$ using a Cytation ${ }^{\mathrm{TM}} 3$ Imaging Multi-Mode Reader (BioTek ${ }^{\circledR}$ Instruments, Inc.).

\section{Antioxidant enzyme activity}

Levels of antioxidant enzymes, i.e. catalase (CAT), glutathione peroxidase (GPx) and superoxide dismutase (SOD), were assessed separately. The CAT, GPx, and SOD assay kits (Cayman Chemical) were used in line with the manufacturer's instructions. Cell cultivation and addition of treatments was carried out in the same manner as described above for LPO assessment. A protein extraction step was performed prior to assessment using the recommended assay buffer for each test. Prior to assessment, the extracted samples were preserved for a short period at $-80{ }^{\circ} \mathrm{C}$. The CAT, GPx, and SOD activity in the samples was determined at $540 \mathrm{~nm}, 340 \mathrm{~nm}$, and $450 \mathrm{~nm}$, respectively, using a Cytation ${ }^{\mathrm{TM}} 3$ Cell Imaging Multi-Mode Reader or EL $\times 808$ multi-plates reader (BioTek ${ }^{\mathbb{R}}$ Instruments, Inc.).

\section{Single cell gel alkaline electrophoresis assay (Comet assay)}

Genotoxicity was assessed using single-cell gel alkaline electrophoresis assay developed by Trevigen Inc. (Gaithersburg, MD, USA). Cells were allowed to grow in 6-well plates at a density of $1 \times 10^{5}$ cells per well, following which treatments were added for $24 \mathrm{~h}$. The cells were then collected mechanically using Cell Scrapers (Greiner Bio-One GmbH, Kremsmünster, Austria). The cells were washed once and then suspended in cold PBS protected from light. The cell suspensions were then mixed with $37^{\circ} \mathrm{C}$-warmed low melting agarose at a ratio of 1:10. This mixture was then applied to Comet slides and allowed to form a gel layer at $4{ }^{\circ} \mathrm{C}$ in the dark for $1 \mathrm{~h}$. The slides were then immersed in lysis buffer in the dark at $4{ }^{\circ} \mathrm{C}$ overnight. The next day, the slides were removed from the lysis solution and immersed in freshly prepared $\mathrm{pH}>13$ alkaline buffer for $20 \mathrm{~min}$ at room temperature. The electrophoresis step was conducted using freshly prepared, pre-cooled $\left(4^{\circ} \mathrm{C}\right)$, alkaline electrophoresis solution $(\mathrm{pH}>13)$ using Cleaver Scientific's horizontal gel electrophoresis system (Cleaver Scientific Ltd, Warwickshire, United Kingdom). Voltage was set at 30 volts with a 300-mA current for 20 min using a Major Science power supply unit (Major Science Innovative Life Sciences Tools, Saratoga, CA, USA). The slides were then washed twice in distilled water for $5 \mathrm{~min}$ each and immersed in $70 \%$ ethanol for $5 \mathrm{~min}$, after which they were placed in an incubator at $37^{\circ} \mathrm{C}$ for $15 \mathrm{~min}$ to allow the gel layers to dry before staining. SYBR ${ }^{\circledR}$ Gold Nucleic Acid Gel Stain (Molecular Probes, Inc., Eugene, OR, USA), diluted in TE buffer (Tris-EDTA) at 7.5 pH, was applied to the gel layers and incubated for $30 \mathrm{~min}$ at room temperature in the dark. The slides were then viewed under an Olympus BX51 Fluorescent Microscope (Olympus Corporation, Tokyo, Japan) at $496 \mathrm{~nm} / 522 \mathrm{~nm}$ excitation/emission to capture comet tails. Analysis of total DNA damage and percentage of DNA in the comet tail, tail moment and olive moment was carried out using OpenComet v.1.3.1software (2016) (Gyori et al. 2014).

\section{Apoptosis detection}

Detection of apoptotic cells was performed using the Annexin V-FITC Kit (Trevigen, Inc.). Cells were allowed to grow in 6-well plates at a density of $10^{5}-10^{6}$ cells per well, following which the treatments were added in the same manner as described above. All assay preparations and steps were conducted following the manufacturer's instructions. Controls were also designed as recommended. Cells were collected using PBS-EDTA to minimise membrane damage caused by enzymatic detachment of cells. A cell incubation step was carried out with Annexin-V (apoptosis) and propidium iodide (necrosis) in binding buffer for $15 \mathrm{~min}$ at room temperature in the 
dark. Imaging of samples and subsequent analysis was performed by flow cytometry on a BD LSRFortessa ${ }^{\mathrm{TM}}$ cell $^{\mathrm{s}}$ analyzer (Becton Dickinson, NJ, USA).

\section{Statistical analysis}

All statistical analyses (e.g. one-way analysis of variance (ANOVA), two and three-factor ANOVA analysis and post hoc analysis of means by the Tukey Honest Significant Difference (HSD) test were carried out using Minitab ${ }^{\circledR}$ Statistical Software 17.3.1 (Minitab Inc., LLC) and Statistica for Windows ${ }^{\circledR} 10$ and/or 12 (StatSoft, Inc., Tulsa, OK, USA).

\section{Results}

\section{Cytotoxicity assessment}

All treatment groups showed significant differences $(P<0.05, P<0.01)$ in cytotoxicity compared to the control group $(0 \mu \mathrm{M}$, Fig. 1). A dose-dependent pattern was observed in response to increased metal concentration in the $\mathrm{CdCl}_{2}$ group $(P<0.01)$. Cytotoxicity peaked at low to moderate concentrations in the $\mathrm{MeHgCl}_{2}$ group $(P<0.01, P<0.05)$, while the effect of $\mathrm{PbCl}_{2}$ was lowest at relatively higher concentrations. An interaction plot of cell-metal-concentration indicated the highest response in both cell groups for $\mathrm{CdCl}_{2}$ $(125 \mu \mathrm{M}, 250 \mu \mathrm{M})$, and the lowest for $\mathrm{PbCl}_{2}$ through all concentrations. Compared to ovarian follicles, Sertoli cells were more vulnerable to $\mathrm{CdCl}_{2}$ and less vulnerable to $\mathrm{MeHgCl}_{2}(P<0.01)$. Ovarian follicles were more sensitive to changes in the concentration of $\mathrm{MeHgCl}_{2}(P<0.05)$.

\section{Oxidative damage}

Regarding LPO, Sertoli cells showed a significant increase $(P<0.01)$ in LPO levels at low concentrations $(15,30 \mu \mathrm{M})$ of $\mathrm{PbCl}_{2}$ (Fig. 2), while ovarian follicles showed a significant increase in LPO levels following $\mathrm{CdCl}_{2}$ treatment $(P<0.01)$, peaking at higher concentrations $(125,250 \mu \mathrm{M})$. Interaction of cell-substance and concentration indicated higher LPO levels in ovarian follicles than Sertoli cells $\left(\mathrm{CdCl}_{2}, P=0.00000\right)$. The LPO levels in the $\mathrm{CdCl}_{2}$ treated group showed a significant increase over LPO levels triggered in both $\mathrm{PbCl}_{2}$ and $\mathrm{MeHgCl}_{2}$ treated groups (post hoc Tukey test, $P<0.01$ ). Again, LPO production in the $\mathrm{PbCl}_{2}$ treated group was more significant than that in the $\mathrm{MeHgCl}_{2}$ treated group $(P<0.01)$.

\section{Antioxidant enzyme activity}

Overall CAT activity was depleted compared to the control group $(P=0.0000)$, and a drastic decrease in GPx levels was also observed $(P=0.00004)$ (Fig. 3). Interaction of cell-substance and concentration indicated the greatest decrease in GPx levels in the $\mathrm{MeHgCl}_{2}$ treated group $(P=0.01)$. Ovarian follicles showed a greater decrease in GPx than Sertoli cells $(P=0.001)$. There was a concentration-dependent elevation in SOD activity in ovarian follicles treated with $\mathrm{MeHgCl}_{2}$ and $\mathrm{PbCl}_{2}(P<0.05)$ (Fig. 4). Sertoli cells showed unstable SOD levels in all metal-treated groups compared with the controls $(P<0.05)$. Interaction of cell-substance and concentration indicated higher SOD activity in Sertoli cells than ovarian follicles $(P=0.0001)$. Further, the $\mathrm{CdCl}_{2}$ and $\mathrm{MeHgCl}_{2}$ treated groups displayed higher SOD activity than the $\mathrm{PbCl}_{2}$ group $(P=0.002)$.

\section{Genotoxicity}

Single-strand DNA damage indicated that Sertoli cells were more vulnerable to total DNA damage $\left(\mathrm{CdCl}_{2}\right.$ : Sertoli cells $=78.75 \%$, ovarian follicles $=70.25 \% ; \mathrm{MeHgCl}_{2}$ : Sertoli cells $=79 \%$, ovarian follicles $=66 \% ; \mathrm{PbCl}_{2}$ : Sertoli cells $=65 \%$, ovarian follicles $=37 \%$ ). ANOVA for DNA percentage in the comet tail indicated a highest percentage of DNA in the comet tail of the $\mathrm{MeHgCl}_{2}$ group $(P=0.001)$. Further, ovarian follicles displayed a higher percentage of DNA in the comet tail than Sertoli cells $(P=0.01)$ (Plate I, Fig. 5). 

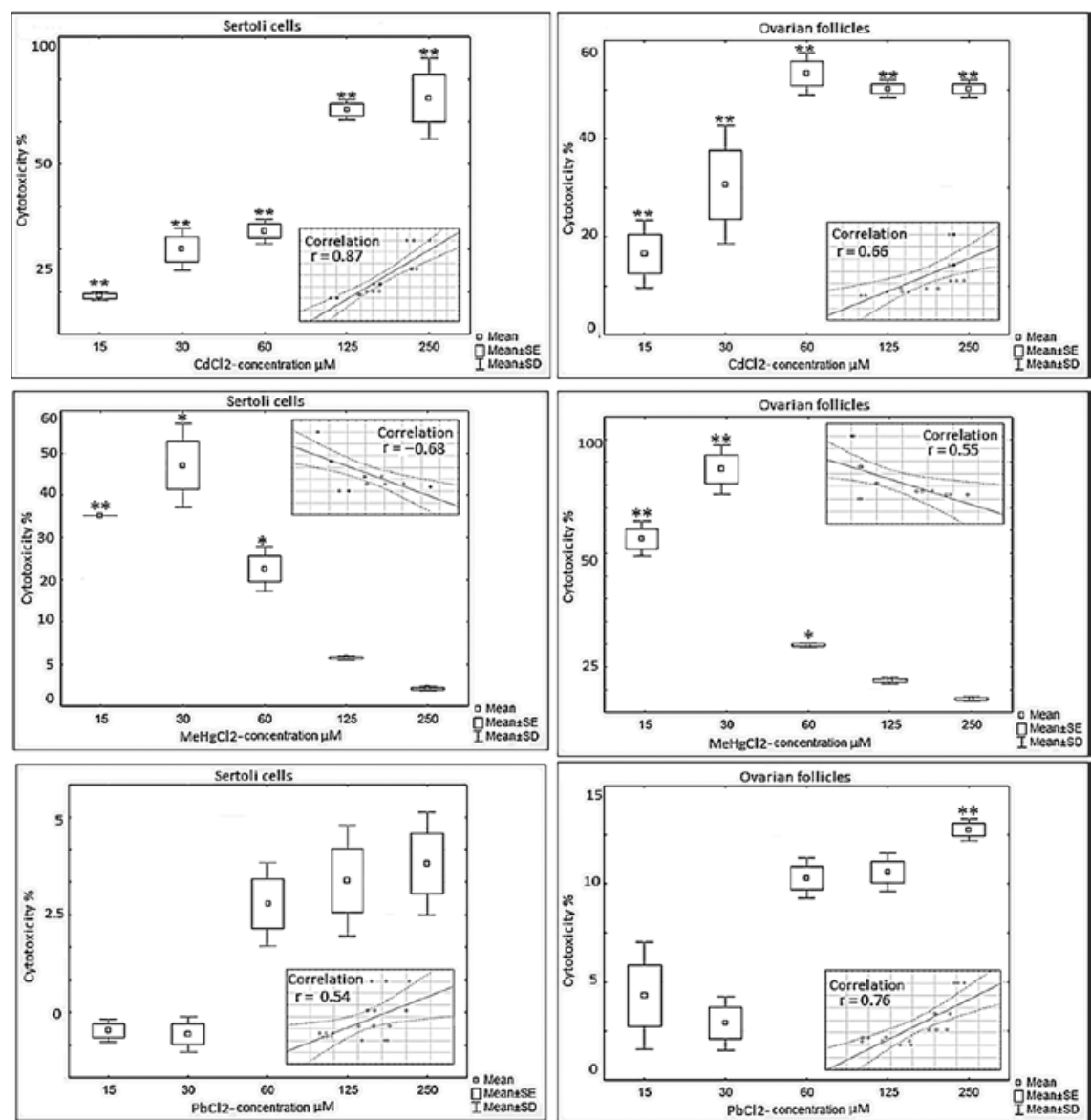

Fig. 1. Cytotoxicity based on the leakage of lactate dehydrogenase (LDH) after $24 \mathrm{~h}$ of exposure to $\mathrm{CdCl}_{2}$, $\mathrm{MeHgCl}_{2}$ and $\mathrm{PbCl}_{2}$

Lactate dehydrogenase activity was calculated as percentage of released LDH in treated groups compared to controls. Correlation boxes express the effect of concentration on the toxicity of metals.

$\mathrm{r}$ - correlation coefficient, SD - standard deviation of mean, SE - standard error of mean, $* P<0.05, * * P<0.01$
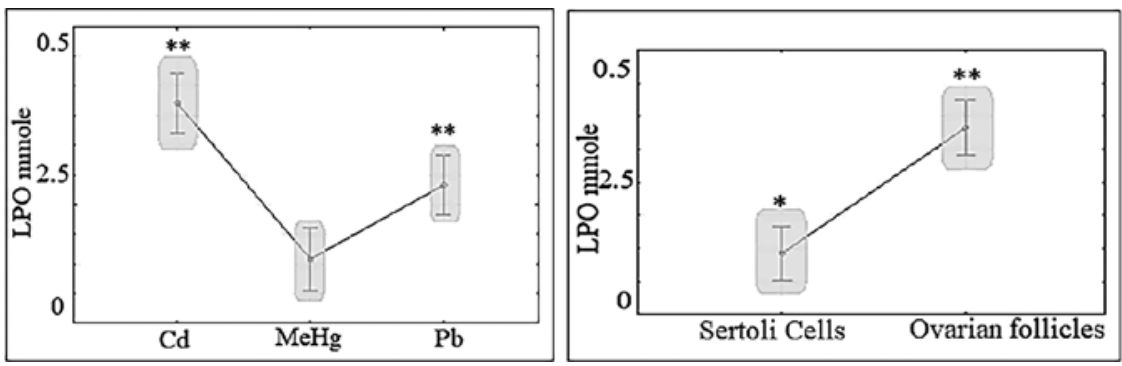

Fig. 2. Lipid peroxidation after $24 \mathrm{~h}$ of exposure to $\mathrm{CdCl}_{2}, \mathrm{MeHgCl}_{2}$ and $\mathrm{PbCl}_{2}$

Lipid hydroperoxide (LPO) levels were calculated from the standard curve. Values from treated cell groups were compared to controls. The interactive effects of cell type-substance and concentration are also displayed.

$* P<0.05, * * P<0.01$ 

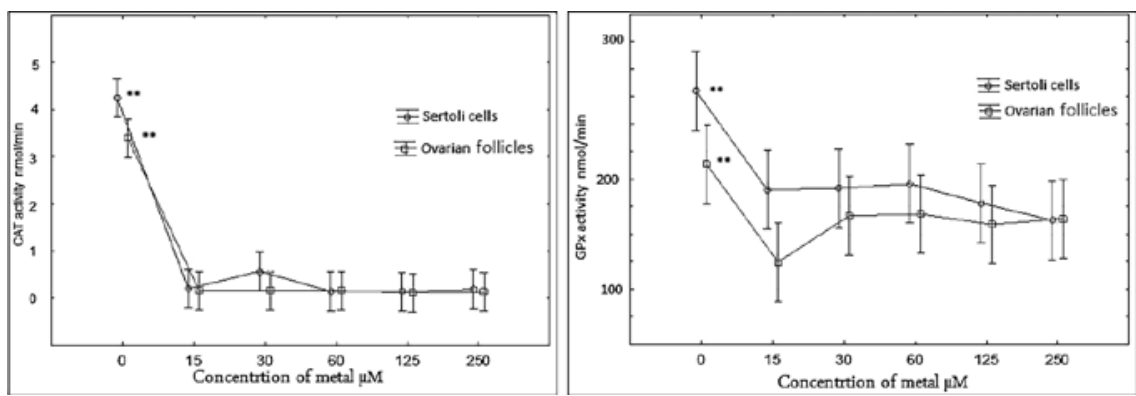

Fig. 3. Activities of antioxidant enzymes catalase (CAT, left) and glutathione peroxidase (GPx, right) in $\mathrm{nmol} / \mathrm{min}$ after $24 \mathrm{~h}$ of exposure to $\mathrm{CdCl}_{2}, \mathrm{MeHgCl}_{2}$ and $\mathrm{PbCl}_{2}$

Antioxidant levels were calculated based on CAT and GPx standards. Values from treated groups were compared to controls.

** $P<0.01$
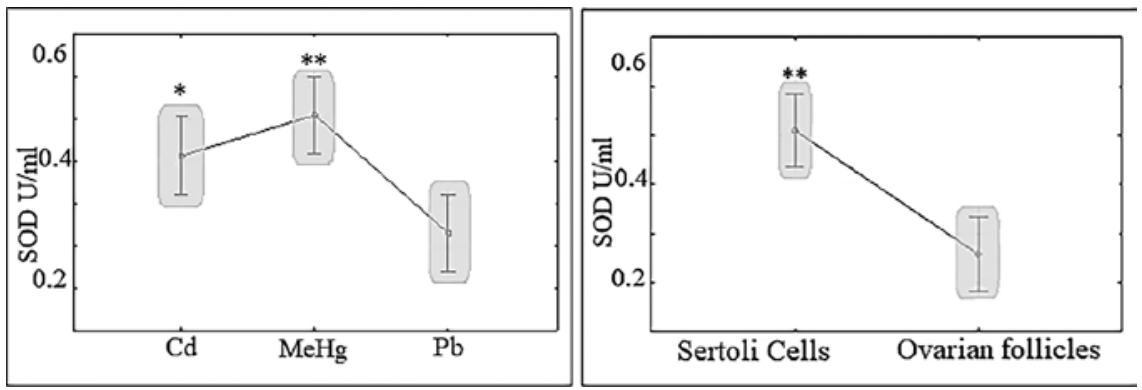

Fig. 4. Activity of superoxide dismutase (SOD) in U/ml after $24 \mathrm{~h}$ of exposure to $\mathrm{CdCl}_{2}, \mathrm{MeHgCl}_{2}$ and $\mathrm{PbCl}_{2}$. Superoxide dismutase levels were calculated based on readings from the SOD standard curve. Values of treated groups were compared to controls. The interactive effects of cell type-substance and concentration are also displayed.

$* P<0.05, * * P<0.01$

\section{Apoptosis detection}

Compared to the controls, a higher rate of apoptosis was detected in the $\mathrm{CdCl}_{2}$ and $\mathrm{PbCl}_{2}$ treated groups $(P=0.00007)$ than the $\mathrm{MeHgCl}_{2}$ group (Plate II, Fig. 6). The $\mathrm{MeHgCl}_{2}$ group showed a significant induction of necrotic/late apoptotic cells in both cellular groups $(P<0.05)$.

\section{Discussion}

Observations from our study indicate oxidative stress-mediated cytotoxicity associated with genotoxicity and apoptosis in reproductive cells derived from a wild game ungulate species. While here we show varying cell responsiveness to different substances and their concentrations, our results are in line with observed reproductive toxicity of metals for other mammalian species. The main adverse toxic effects of heavy metals, as well as many other natural and anthropogenic toxins, are impairment of the sex glands connected with disruption of neuroendocrine mechanisms (Apostoli et al. 2007; Damkova et al. 2009, 2011; Paskova et al. 2011; Pikula et al. 2013; Hruba et al. 2019). 
The concentration-dependent cytotoxicity observed in our $\mathrm{CdCl}_{2}$-treated group matches the Cd toxicity observed previously. The peak LDH leakage levels observed in our study indicated that Sertoli cells were more sensitive to $\mathrm{Cd}$. Cytotoxicity, indicated by the dose-dependentrelationship, was more evident with increased concentrations $(125-250 \mu \mathrm{M})$, with cell death based on LDH leakage reaching up to $83 \%$ for Sertoli cells $(250 \mu \mathrm{M})$ compared to $57 \%$ for ovarian follicles $(250 \mu \mathrm{M})$. It was clearly demonstrated that $\mathrm{Cd}$ follows a concentration-dependent relationship and is a potent source of decreased cell viability. The high sensitivity of Sertoli cells to Cd toxicity is consistent with Cd inducing testicular injury by targeting vasculature-dense structures within the physiological system (Siu et al. 2010). Cytotoxicity in ovarian follicles was significantly less severe, most likely associated with increased LPO levels. In fact, $\mathrm{Cd}$ toxicity toward the female reproductive organs is more connected to functional perturbation, with the formation of lipid hydroperoxides being dependent on lipid content in the cell membrane and organelles. Hence, the dense lipid content and membranous fats in ovarian follicles (Hamilton and Seamark 1978) may play an important role in increased LPO. The by-products of LPO can also disrupt the mitochondrial redox balance by interfering with follicular cell function in steroidogenesis, i.e. the process controlled by steroidogenic enzymes located in mitochondrial membranes and the endoplasmic reticulum of follicular theca cells (Magoffin 2005), previously observed in Cd toxicity in rats (Wang et al. 2015). Cd-induced cytotoxicity, followed by modulations in the cell oxidative system observed in our in vitro testing, may explain functional failure in both sexes exposed to $\mathrm{Cd}$ in vivo (Piasek and Laskey 1999).

Cell vulnerability to $\mathrm{MeHg}$ showed an opposite reaction to that of $\mathrm{Cd}$, though the same pattern was observed in both cell groups. LDH peaked at low concentrations in ovarian follicles and moderate concentrations in Sertoli cells $(15,30$, and $60 \mu \mathrm{M})$. The necrotic potential of $\mathrm{MeHg}$ was also indicated by the levels of decreased cell viability observed (based on detection of apoptosis), with exposure to $\mathrm{MeHg}$ inducing increased necrosis/late apoptosis in cells (Fig. 6). At higher concentrations, however, cytotoxicity showed a distinct decline. As mercuric compounds are believed to interfere with the sulphhydryl component in the LDH molecule (Singerman 2000), the effects observed may be attributable to inactivation of $\mathrm{LDH}$ induced by $\mathrm{Hg}$.

While Sertoli cells showed no clear signs of membrane damage or cell death from $\mathrm{Pb}$-induced cytotoxicity, there was a slight cytotoxic effect in ovarian follicles. Nevertheless, $\mathrm{Pb}$-mediated oxidative damage from generation of LPO, perturbation of antioxidants, DNA damage and apoptosis were seen in both cellular groups. Formation of LPO, with slight evidence of cytotoxicity, indicates substance-specific cell responsiveness to $\mathrm{Pb}$ toxicity. As suggested by Girotti (1998), under certain circumstances, lipid peroxides may undergo reductive degradation, leading either to their depletion or an increase in cytotoxicity. Hence, at a certain level, LPO, or by-products triggered by $\mathrm{Pb}$ toxicity, may promote rapid cell protection/termination mechanisms, resulting in a greater likelihood of cell survival (Girotti 1998). Both these mechanisms (stimulation/inhibition of antioxidants or apoptosis) were activated in the $\mathrm{Pb}$-treated groups in this study, regardless of cell membrane damage. In other studies, however, high concentrations of $\mathrm{Pb}$ caused severe physiological and morphological changes, with exposure-associated findings including either perturbation or complete arrest of spermatogenesis, as well as a severe decrease in the germ cell layer (Wadi and Ahmad 1999). Similar effects have been observed in the ovarian tissue of female mice, indicating mild to critical histopathological and physiological changes based on dosing (Taupeau et al. 2001).

The DNA damage induced by $\mathrm{Pb}$ in our experiment, particularly on Sertoli cells, indicates non-cytotoxic genotoxicity that is somewhat apoptosis-provocative. Lead is a competitive metal known to induce toxicity via antagonism with essential elements and intervention with intracellular enzymatic reactions (Wani et al. 2015), with Pb-antagonism 
contributing to its genotoxicity through interruption of DNA-binding molecules. Lead is believed to replace zinc in specific zinc-containing proteins protecting sperm DNA during spermatogenesis, resulting in sperm deformities (Wani et al. 2015). In comparison, the structure of Sertoli cells forms a tight junction between cells. Metallic ions enter the cell through this junction via specific trans-membranous proteins. In addition to its competitiveness, $\mathrm{Pb}$ has an affinity for binding to specific low-molecular-weight proteins, facilitating its bioavailability and thereby increasing its toxic impact should constant low doses be available (Fowler 1998). In addition, $\mathrm{Pb}$ has a strong ability to interfere with transportation channels located on cytoplasmic membranes or at cell junctions, thereby enabling cell entry (Florea et al. 2013). Our own observations indicate that $\mathrm{Pb}$ was only able to induce perturbation of membranous lipids at low concentrations. This could mean that Sertoli cells failed to recognise $\mathrm{Pb}$ at higher concentrations, possibly by confusing it with other metallic substances, and so allowed it to pass through the membrane. As a result, higher LPO production and DNA damage were observed in Sertoli cells compared to ovarian follicles.

Extreme depletion in CAT activity, regardless of heavy metal concentration, occurred in all treatment groups. CAT depletion and inhibition of GPx in both cell groups may be linked to disruption of LPO (Girotti 1998). Both enzymes have been implicated in reducing hydroxides and conversion of superoxide into water and molecular oxygen or oxidised glutathione and water. This prevents conversion of LPO products into reactive hydroxyl radicals that attack DNA and damage it. Heavy metals are also suspected to induce SOD expression through promotion of the SOD1 gene. Overexpressed or mutated SOD1 genes provide instructions for making SOD through possible participation of metalresponsive mechanisms (Carocci et al. 2014; Yoo et al. 1999). These findings regarding SOD activity, along with the inhibition of GPx, point to some form of mitochondrial dysfunction.

Superoxide dismutase is predominantly responsible for scavenging by-products of mitochondrial oxidative phosphorylation via reduction of superoxide free radicals. Thus, strand-break DNA damage and cell apoptosis may represent secondary effects of mitochondrial injury. During stressful conditions, such as during oxidative DNA damage, the cell adopts a protective mechanism based on activation of mitochondrial-controlled apoptosis. In our study, MeHg inhibited GPx and induced SOD in the two cell types. While wildlife species are at risk from exposure to both inorganic and organic forms of mercury, it is generally organic mercury which is more toxic (Wolfe et al. 1998), making our reproductive toxicity study using $\mathrm{MeHg}$ more relevant. Mercuric compounds are presumed to harm the mitochondria through depletion of glutathione following thiol-binding. Glutathione, on the other hand, plays a key role in scavenging free radicals responsible of DNA peroxidation (Carocci et al. 2014). Thus, this could be a principal route of $\mathrm{Hg}$-induced DNA damage. Mercury is also thought to be genotoxic through direct targeting of DNA molecules, thereby causing chromosomal abnormalities (Crespo-López et al. 2009). Previous studies on reproductive genotoxicity of $\mathrm{Hg}$ have confirmed some depression in the synthesis of DNA and sperm abnormalities, with mice subjected to single-dose administration of $\mathrm{Hg}$ and laboratory-exposed monkeys suffering spermatogonia (Apo stoli et al. 2007).

DNA damage in both cell types caused by $\mathrm{Cd}$ might also be related to a redox perturbation. In vitro studies on $\mathrm{Cd}$ genotoxicity to reproductive structures provide strong evidence of interference with DNA in various cell types of different species. For example, Cd was found to induce oxidative-mediated DNA damage at different concentrations in primary cultures of rat Leydig cells and in Sertoli cells derived from piglets (Yang et al. 2003; Zhang et al. 2010). Likewise, $\mathrm{CdCl}_{2}$ caused chromatin condensation, DNA fragmentation and apoptosis on granulosa cells from chicken ovarian follicles at a single low dose $(5 \mu \mathrm{M})$. 
These events were analogous to a decrease in cell number and viability ( $\mathrm{Jia}$ et al. 2011). Cadmium, unlike $\mathrm{Hg}$, is known to only harm DNA secondarily to transformation of Cdinduced reactive oxygen species (ROS) into highly active hydroxyl radicals. These active radicals are then able to attack DNA and break its strands (Bertin and Averbeck 2006). Additionally, production of ROS may occur through interference with the transmembrane redox reaction in mitochondria, and through inhibition of complex III in the mitochondrial electronic transport chain (Bertin and Averbeck 2006). Consequently, damage to the mitochondrial membrane may develop and prompt apoptosis, as observed in our experiment.

To conclude, repeated and chronic exposure of wild game ungulates to toxic metals in their natural habitat can impair their reproduction, with reproductive function perturbation initiated at the cellular/molecular level. Importantly, the present study confirmed the utility of cell culture models for extrapolating data on adverse effects of toxic substances in wildlife species, in line with the 'Three Rs' concept of animal research (Flieger et al. 2016; Kovacova et al. 2016; Abdelsalam et al. 2020).

\section{Acknowledgements}

This study was supported through Grant No. 226/2018/FVHE of the Internal Grant Agency of the University of Veterinary and Pharmaceutical Sciences Brno. We are grateful to Dr. Kevin Roche for correction and improvement of the English text.

\section{References}

Abdelsalam EEE, Bandouchova H, Heger T, Kanova M, Kobelkova K, Nemcova M, Piacek V, Sedlackova J, Seidlova V, Vitula F, Pikula J 2020: Polychlorinated biphenyl toxicity in the thyroid gland of wild ungulates: an in vitro model. Acta Vet Brno 89: 151-162

Apostoli P, Telišman S, Sager PR 2007: Reproductive and developmental toxicity of metals. In: Nordberg GF, Fowler BA, Nordberg M, Friberg LT (Eds): Handbook on the Toxicology of Metals. Third edn, Academic Press, Burlington, MA, USA, 975 p.

Ariza ME, Bijur GN, Williams MV 1999: Environmental Metal Pollutants: Sources and Determinants of Toxicity. In: Ariza ME, Bijur GN, Williams MV (Eds): Enivronmental Metal Pollutants, Reactive Oxygen Intermediaries and Genotoxicity. Springer, Boston, MA, USA, 189 p.

Bertin G, Averbeck D 2006: Cadmium: cellular effects, modifications of biomolecules, modulation of DNA repair and genotoxic consequences (a review). Biochimie 88: 1549-1559

Carocci A, Rovito N, Sinicropi MS, Genchi G 2014: Mercury Toxicity and Neurodegenerative Effects. In: Whitacre DM (Ed.): Reviews of Environmental Contamination and Toxicology. Springer International Publishing, Cham, Germany, pp. 1-18

Čelechovská O, Malota L, Zima S 2008: Entry of heavy metals into food chains: A 20-year comparison study in Northern Moravia (Czech Republic). Acta Vet Brno 77: 645-652

Crespo-López ME, Macêdo GL, Pereira SID, Arrifano GPF, Picanço-Diniz DLW, do Nascimento JLM, Herculano AM 2009: Mercury and human genotoxicity: Critical considerations and possible molecular mechanisms. Pharmacol Res 60: 212-220

Cupertino MC, Novaes RD, Santos EC, Neves AC, Silva E, Oliveira JA, Matta SLP 2017: Differential susceptibility of germ and Leydig cells to cadmium-mediated toxicity: Impact on testis structure, adiponectin levels, and steroidogenesis. Oxid Med Cell Longev 2017: 1-11

Damkova V, Sedlackova J, Bandouchova H, Peckova L, Vitula F, Hilscherova K, Paskova V, Kohoutek J, Pohanka M, Pikula J 2009: Effects of cyanobacterial biomass on avian reproduction: a Japanese quail model. Neuroendocrinol Lett 30: 205-210

Damkova V, Paskova V, Sedlackova J, Bandouchova H, Hilscherova K, Novotny L, Peckova L, Vitula F, Pohanka M, Pikula J 2011: Testicular toxicity of cyanobacterial biomass in Japanese quails. Harmful Algae 10: 612-618

Flieger M, Bandouchova H, Cerny J, Chudíčková M, Kolarik M, Kovacova V, Martínková N, Novák P, Šebesta O, Stodůlková E, Pikula J 2016: Vitamin B2 as a virulence factor in Pseudogymnoascus destructans skin infection. Sci Rep 6: 33200

Florea AM, Taban J, Varghese E, Alost BT, Moreno S, Büsselberg D 2013: Lead ( $\left.\mathrm{Pb}^{2+}\right)$ neurotoxicity: Ionmimicry with calcium $\left(\mathrm{Ca}^{2+}\right)$ impairs synaptic transmission. A review with animated illustrations of the pre- and post-synaptic effects of lead. Glob J Health Sci 2013: 4

Fowler BA 1998: Roles of lead-binding proteins in mediating lead bioavailability. Environ Health Persp 106: 1585-1587

Garcia MHDM, Moreno DH, Rodriguez FS, Beceiro L, Fidalgo ALE, Lopez MP 2011: Sex- and age-dependent accumulation of heavy metals $(\mathrm{Cd}, \mathrm{Pb}$ and $\mathrm{Zn}$ ) in liver, kidney and muscle of roe deer (Capreolus capreolus) from NW Spain. J Environ Sci Health A 46: 109-116 
Girotti AW 1998: Lipid hydroperoxide generation, turnover, and effector action in biological systems. J Lipid Res 39: 1529-1542

Gyori BM, Venkatachalam G, Thiagarajan PS, Hsu D, Clement MV 2014: OpenComet: an automated tool for comet assay image analysis. Redox Biol 2: 457-465

Hamilton RP, Seamark RF 1978: Lipid content of sheep ovarian follicles in culture. Aust J Biol Sci 31: 621-628

Hruba H, Abdelsalam EEE, Anisimov N, Bandouchova H, Havelkova B, Heger T, Kanova M, Kovacova V, Nemcova M, Piacek V, Sedlackova J, Vitula F, Pikula J 2019: Reproductive toxicity of fluoroquinolones in birds. BMC Vet Res 15: 209

Jia Y, Lin J, Mi Y, Zhang C 2011: Quercetin attenuates cadmium-induced oxidative damage and apoptosis in granulosa cells from chicken ovarian follicles. Reprod Toxicol 31: 477-485

Kala S, Kaushik R, Singh KP, Kadam PH, Singh MK, Manik RS, Singla SK, Palta P, Chauhan MS 2012: In vitro culture and morphological characterization of prepubertal buffalo (Bubalus bubalis) putative spermatogonial stem cell. J Assist Reprod Gen 29: 1335-1342

Kovacova V, Abdelsalam EEE, Bandouchova H, Brichta J, Havelkova B, Piacek V, Vitula F, Pikula J 2016: Cytotoxicity of ketamine, xylazine and Hellabrunn mixture in liver-, heart- and kidney-derived cells from fallow deer. Neuroendocrinol Lett 37 (Suppl. 1): 78-83

Kuiters AT 1996: Accumulation of cadmium and lead in red deer and wild boar at the Veluwe, The Netherlands. Vet Quart 18 (Suppl. 3): 134-135

Lazarus M, Orct T, Blanuša M, Vicković I, Šoštarić B 2008: Toxic and essential metal concentrations in four tissues of red deer (Cervus elaphus) from Baranja, Croatia. Food Addit Contam A 25: 270-283

Magoffin DA 2005: Ovarian theca cell. Int J Biochem Cell Biol 37: 1344-1349

Morris P 1972: A review of mammalian age determination methods. Mammal Rev 2: 69-104

Penna S, Pocino M, Marval MJ, Lloreta J, Gallardo L, Vila J 2009: Modifications in rat testicular morphology and increases in IFN- $\gamma$ serum levels by the oral administration of subtoxic doses of mercuric chloride. Syst Biol Reprod Med 55: 69-84

Piasek M, Laskey JW 1999: Effects of in vitro cadmium exposure on ovarian steroidogenesis in rats. J Appl Toxicol 19: 211-217

Paskova V, Paskerova H, Pikula J, Bandouchova H, Sedlackova J, Hilscherova K 2011: Combined exposure of Japanese quails to cyanotoxins, Newcastle virus and lead: Oxidative stress responses. Ecotox Environ Safe 74: 2082-2090

Pikula J, Hajkova P, Bandouchova H, Bednarova I, Adam V, Beklova M, Kral J, Ondracek K, Osickova J, Pohanka M, Sedlackova J, Skochova H, Sobotka J, Treml F, Kizek R 2013: Lead toxicosis of captive vultures: case description and responses to chelation therapy. BMC Vet Res 9: 11

Pokorny B 2000: Roe deer Capreolus capreolus as an accumulative bioindicator of heavy metals in Slovenia. Web Ecol 1: 54-62

Singerman A 2000: Exposure to Toxic Metals: Biological Effects and Their Monitoring. In: Vercruysse A (Ed.): Hazardous Metals in Human Toxicology. First edn, Elsevier Science Publisher, Amsterdam, Netherlands, 334 p.

Siu ER, Mruk DD, Porto CS, Cheng CY 2010: Cadmium-induced testicular injury. Toxicol Appl Pharm 238: 240-249

Stadnicka A 1980: Localization of mercury in the rat ovary after oral administration of mercuric chloride. Acta Histochem 67: 227-233

Svoboda M, Drápal J, Haruštiaková D, Svobodová Z 2020: A multiannual survey of cadmium content in pig tissues collected in the Czech Republic during the years 2015-2019. Acta Vet Brno 89: 349-355

Swim HE, Parker RF 1958: The role of carbon dioxide as an essential nutrient for six permanent strains of fibroblasts. J Biophys Biochem Cytol 4: 525-528

Taupeau C, Poupon J, Nomé F, Lefèvre B 2001: Lead accumulation in the mouse ovary after treatment-induced follicular atresia. Reprod Toxicol 15: 385-391

Wadi SA, Ahmad G 1999: Effects of lead on the male reproductive system in mice. J Toxicol Environ Health Part A 56: 513-521

Wang Y, Wang X, Wang Y, Fan R, Qiu C, Zhong S, Wei L, Luo D 2015: Effect of cadmium on cellular ultrastructure in mouse ovary. Ultrastruct Pathol 39: 324-328

Wani AL, Ara A, Usmani JA 2015: Lead toxicity: A review. Interdiscip Toxicol 8: 55-64

Wolfe MF, Schwarzbach S, Sulaiman RA 1998: Effects of mercury on wildlife: a comprehensive review. Environ Toxicol Chem 17: 146-160

Yang JM, Arnush M, Chen QY, Wu XD, Pang B, Jiang XZ 2003: Cadmium-induced damage to primary cultures of rat Leydig cells. Reprod Toxicol 17: 553-560

Yoo HY, Chang MS, Rho HM 1999: Heavy metal-mediated activation of the rat $\mathrm{Cu} / \mathrm{Zn}$ superoxide dismutase gene via a metal-responsive element. Mol Gen Genet 262: 310-313

Zhang M, He Z, Wen L, Wu J, Yuan L, Lu Y, Guo C, Zhu L, Deng S, Yuan H 2010: Cadmium suppresses the proliferation of piglet Sertoli cells and causes their DNA damage, cell apoptosis and aberrant ultrastructure. Reprod Biol Endocrinol 8: 97 
Plate I

Abdelsalam E. E. E. et al.: Reproductive ... pp. 277-286

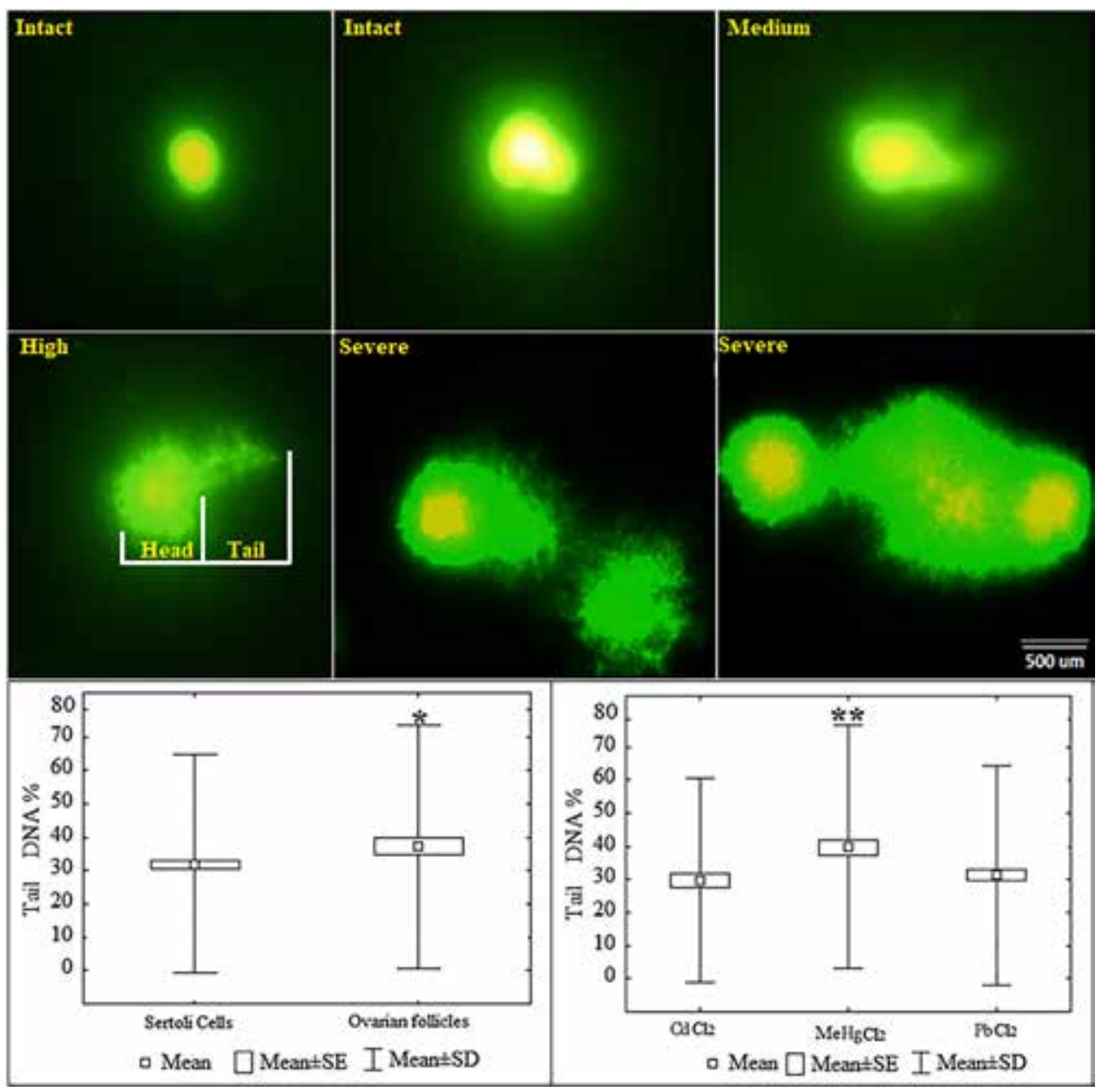

Fig. 5. Genotoxicity (DNA damage) indicated as a single strand break after 24 h of exposure to $\mathrm{CdCl}_{2}, \mathrm{MeHgCl}_{2}$ and $\mathrm{PbCl}_{2}$

Top $=$ representative images for different degrees of damage severity and formation of comet head and tail (ovarian follicles: $\mathrm{MeHgCl}_{2}$ group); bottom = the interactive effects of cell type-substance and concentration on the percentage of DNA in the comet tail.

$\mathrm{SD}=$ standard deviation of the mean, $\mathrm{SE}=$ standard error of the mean, $* P<0.05, * * P<0.01$ 
Plate II
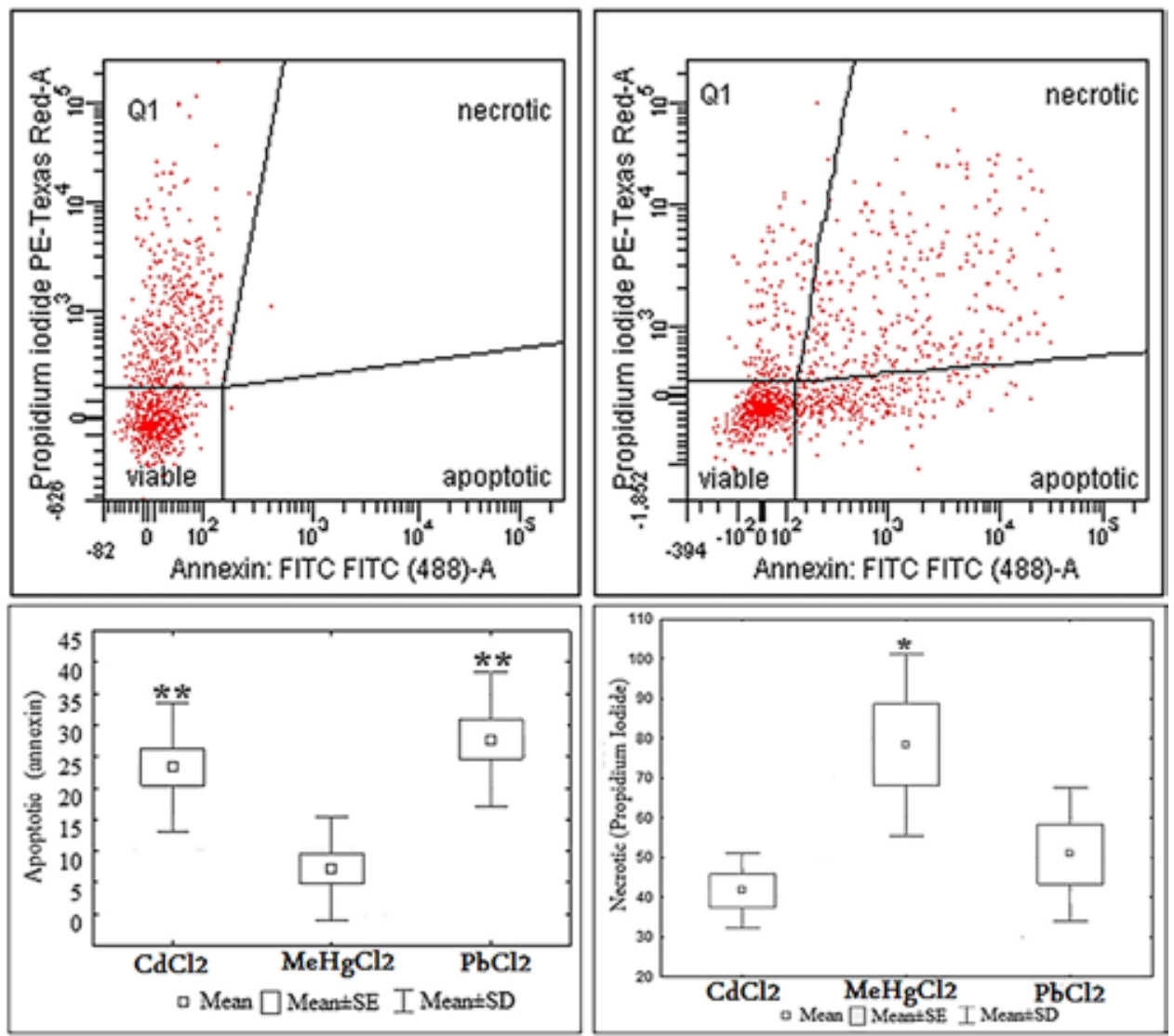

Fig. 6. Cell apoptosis detected after $24 \mathrm{~h}$ of exposure to $\mathrm{CdCl}_{2}, \mathrm{MeHgCl}_{2}$ and $\mathrm{PbCl}_{2}$

Top $=$ representation of apoptotic Sertoli cells exposed to $\mathrm{CdCl}_{2} ;$ left $=$ control $0 \mu \mathrm{M}$; right $=60 \mu \mathrm{M} \mathrm{CdCl}_{2}$; bottom $=$ interactive effects of cell type-substance and concentration in induction of apoptosis (left) or necrosis (right). $\mathrm{SD}=$ standard deviation of the mean, $\mathrm{SE}=$ standard error of the mean, $* P<0.05, * * P<0.01$ 